\title{
Verification of Acquisition Duty of Right on Land and Building by Office for Management of Finance and Regional Revenue towards Conveyance of Rights in Pariaman
}

\author{
Ulthri Aurora; Yuslim; Khairani \\ Faculty of Law, Andalas University, Padang, Indonesia
}

http://dx.doi.org/10.18415/ijmmu.v6i5.1098

\begin{abstract}
The objectives of this research are: 1) to know How the Verification of Acquisition Duty of Right on Land and Building Made by Land Deed Official is; 2) to know How the Verification of Acquisition Duty of Right on Land and Building by Office for Management of Finance and Regional Revenue towards inheritance is; 3) to know How Legal Consequence of Verification of Acquisition Duty of Right on Land and Building by Office for Management of Finance and Regional Revenue towards trade contract. The approach method used in this thesis is a judicial-sociological or empirical approach method, known also as socio-legal research. Verification of Acquisition Duty of Right on Land and Building Determination on Trade by Office for Management of Finance and Regional Revenue of Pariaman is based on market value that should be based on transaction value as in line with Regional Regulation on Verification of Acquisition Duty of Right on Land and Building of Pariaman and it also does not fulfill the legal requirement of agreement and the principle of contracting freedom. Verification of Acquisition Duty of Right on Land and Building on Inheritance done by Office for Management of Finance and Regional Revenue in Pariaman is based on market value which is in accordance with the Regional Regulation of Acquisition Duty of Right on Land and Building of Pariaman, its processes is similar to Acquisition Duty of Right on Land and Building on Trade which are field survey and by seeing the conveyance of rights previously. The legal consequence of verification of Acquisition Duty of Right on Land and Building determination by Office for Management of Finance and Regional Revenue towards Land Deed Official specifically trade contract which is null and void because it violates the principle of contracting freedom and the legal requirement of contract.
\end{abstract}

Keywords: Verification; Acquisition Duty of Right on Land and Building; Trade; Inheritance

\section{Introduction}

Land Deed Official in performing his works cannot be separated far from tax, as stipulated in the Regional Regulation of Acquisition Duty of Right on Land and Building Article 9 Sub-section (1) regulating that "Land Deed Ofiicial is only able to sign the conveyance of rights on land after the taxpayers submit their tax payment slip or regional tax payment slip". It is related to conveyance of rights 
that will be performed by the parties (Darusman, 2016). Therefore, it is acceptable if the owner or the one obtaining the rights on land and building (which are the parts of the earth) submits a part of economical value to the government. The submission of a part of economical value from the acquisition of land and building is manifested by paying tax, in this case, Acquisition Duty of Right on Land and Building (Asshiddiqie, 2003). The collection of Acquisition Duty of Right on Land and Building still pays attention on the principle of fairness for community with low-economy group and with non-taxable income through Acquisition Value of Right on Land and Building (Juwana, 2006).

The tariff in the verification of Acquisition Duty of Right on Land and Building determined by the Regional Regulation is based on transaction cost or Sales Value of Taxable Object on Land and Building Tax. The provision from Article 5 of Regional Regulation of Acquisition Duty of Right on Land and Building sets that the highest imposition base of Acquisition Duty of Right on Land and Building verification is of 5\% (five percents) from the total of tax rate determined. According to the writer's observation, it is frequent to find different opinions between taxpayers and Office for Management of Finance and Regional Revenue of Pariaman as well as Land Deed Official in the working region of Pariaman regarding the value of Acquisition Duty of Right on Land and Building verification. In Article 4 Number (2) in Regional Regulation on Acquisition Duty of Right on Land and Building, it is clear that Acquisition Value of Taxable Object in Acquisition Duty of Right on Land and Building is transaction value. In fact, in the field, the parties of Office for Management of Finance and Regional Revenue have their own determination value which are frequently not in accordance with the transaction value of the parties whereas trade contract on land and or building done by the parties are conducted based on the principle of contracting freedom in which the contract is valid as a rule for the parties who make it and must be respected by all parties including Office for Management of Finance and Regional Revenue of Pariaman (Pratama Putri, 2018).

However, in its practice, the parties of Office for Management of Finance and Regional Revenue of Pariaman frequently perform refusal towards the price of trade that has been agreed by the parties. The price of trade made in the form of Acquisition Duty of Right on Land and Building verification is the price agreement between the seller and the buyer that are not conflicting with all prevailing regulations. Verification is the part of research procedures on Acquisition Duty of Right on Land and Building as in Article 2 sub-section (5) in Mayor Regulation of Pariaman Number 13 of 2011 Regarding System and Procedure of Acquisition Duty of Right on Land and Building Collection in Pariaman Region that the research procedure of Regional Tax Payment Slip of Acquisition Duty of Right on Land and Building is the verification procedure done by Working Unit of Regional Finance Management on validity and completeness of Regional Tax Payment Slip of Acquisition Duty of Right on Land and Building and its supporting documents.

The parties performing trade on land and or building is based on Acquisition Value of Taxable Object and not based on Sales Value of Taxable Object as mentioned in Regional Regulation of Pariaman Number 2 of 2011 regarding Acquisition Duty of Right on Land and Building. It leads to loss for most taxpayers because the Acquisition Value of Taxable Object of taxpayers in the verification of Acquisition Value of Taxable Object is not in line with the transaction value in which in fact it is much lower than the the Acquisition Value of Taxable Object and requires the taxpayers to pay Acquisition Duty of Right on Land and Building higher.

It is clearly conficting with the Regional Regulation of Pariaman Number 2 of 2011 regarding Acquisition Duty of Right on Land and Building. It has been clear that the Acquisition Value of Taxable Object in Acquisition Duty of Right on Land and Building is transaction value. Consequently, the purpose of law expected is not achieved namely the acquisition of legal certainty for personal or agency that will obtain rights on land and building. In other words, the policy that has been made to perform Acquisition 
Duty of Right on Land and Building collection in Pariaman still not shows effective and efficient policy yet (Adjie, 2008).

In its manifestation, the verification process of Acquisition Duty of Right on Land and Building spends longer time so that it will lead to loss for the parties and the worst thing is if one of the parties are dead while the parties still not sign trade contract of Land Deed Official, therefore, problems in form of loss by one of the parties will rise because it will be related to the heir. This is what makes the writer interested in obtaining more information regarding verification determination of Acquisition Duty of Right on Land and Building and the continuance of Office for Management of Finance and Regional Revenue of Pariaman on this incompatibility and its legal consequence for Land Deed Official in Pariaman.

\section{Research Method}

The approach method used in doing this thesis research is a judicial-sociological/empirical approach method or also known as socio-legal research (Banakar \& Travers, 2005). Doing approach by field research and library research can answer the research questions. In this research, the writer conducted interviews with the parties in Office for Management of Finance and Regional Revenue and some Land Deed Officials in Pariaman. What is meant by judicial-sociological/empirical research is a legal research approach method that functions to see law in real meaning and investigates how the law works in community. ${ }^{1}$

The specification of this research is descriptive. A descriptive research is meant to provide detailed understanding towards social phenomena based on its indication (Lambert \& Lambert, 2012). This present research portrays Acquisition Duty of Right on Land and Building by Office for Management of Finance and Regional Revenue towards Conveyance of Rights on Land in Pariaman.

The primary data collected are related to Determination Verification of Acquisition Duty of Right on Land and Building by Office for Management of Finance and Regional Revenue towards Conveyance of Rights on Land in Pariaman. The primary data that will be used are all recapitulation of interview results that will be done by the writer. In addition, the secondary data are obtained from books, literatures, articles from newspaper, scientific writings, and regulations regarding the problems of research (Lawless et al., 2010). The materials of secondary data are from legal materials that can help to analyze, understand, and explain the materials of primary data such as research results, scientific papers from law experts, and theories of scholars regarding the problems of research. Besides, law materials of tertiary data are from dictionary, encyclopedia, maganize, newspaper, and so forth (McConville, 2017).

The interviews in this research are done by semi-structure way by using guidance of interview or list of questions both open and closed questions in order to obtain much information from the parties that are taken as respondents. In this research, the interviews were conducted with the Section Head of Acquisition Duty of Right on Land and Building Division and some other officers in the building of Regional Government of Pariaman in Office for Management of Finance and Regional Revenue. It is because the Verification Determination of Acquisition Duty of Right on Land and Building is done by Office for Management of Finance and Regional Revenue of Pariaman. Document study is used to collect

\footnotetext{
${ }^{1}$ Faculty of Law, Muhammadiyah University of West Sumatera, Bukittinggi, Legal Writing Guidance on Proposal Seminar and Comprehensive Exam, 2015, p.11.
} 
secondary data in form of opinions or writings of the experts or others who study literary materials regarding to this research.

The data collected in this research both in form of library data and in form of field data will be analyzed by using qualitative data analysis in which the research data are explained by words without using numbers by referring to prevailing laws or norms.

\section{Research Result and Discussion}

Verification Determination of Acquisition Duty of Right on Land and Building towards Conveyance of Rights on Trade by Officers in Pariaman

Taxable object of Acquisition Duty of Right on Land and Building is the acquisition of right on land and or building, the acquisition of right on land and building including: conveyance of rights (trading, bartering, granting, inheriting, revenue in company or other legal people, separation of rights that cause conveyance, buyers selection in auction, the realization of judge decision that has permanent law power, reward) and the granting of new rights (the continuance of conveyance of rights).

The law base of tax collection realization of Acquisition Duty of Right on Land and Building is Law Number 21 of 1997 as has been amended with Law Number 20 of 2000 regarding Acquisition Duty of Right on Land and Building. These laws amend the Ordinance of Title Transfer Fee Staatsblad 1924 Number 291. To conduct tax collection, law base is indeed significant in order that its realization is in line with the prevailing laws. Law base to conduct tax collection leads to law of tax that is the whole regulation of tax collection covering regulations to conduct tax collection. In it, it also explains the taxable subjects and taxable objects, the form and the number of payment, payable of tax period, and the obligation for taxpayer period.

Law of tax prevailing in the present time is simpler than the old law, but the community feels more difficult to understand the law. It is because in its practice, still many taxpayers who do not understand the regulation of Acquisition Duty of Right on Land and Building. ${ }^{2}$ Law Number 21 of 1997 that has been amended with Law Number 20 of 2000 regarding Acquisition Duty of Right on Land and Building adopts several tax principles specifically tax collection of Acquisition Duty of Right on Land and Building which uses self-assessment system. Self-assessment system means that the taxpayers are required to calculate, to pay their taxes themselves, and to submit their payable taxes as in line with the law of tax so that the determination of the payable tax total is given to the taxpayers.

From the definition of self-assessment, it can be concluded that the realization of tax collection of Acquisition Duty of Right on Land and Building requires the taxpayers to understand the ways and to master the regulations of tax as set in the prevailing law of tax so that this self-assessment system is likely possible to the taxpayer to get difficulties in paying the tax. It is like in filing form of Acquisition Duty of Right on Land and Building which uses the formula of Acquisition Duty of Right on Land and Building and the value as well as its calculation result must be correct unless it will lead to the result incompability with the tax that must be paid.

In its practice, the difficulties faced by the taxpayers also demand the readiness of some parties. In Pariaman, the government gives authority to the Public Notary/Land Deed Official to help the taxpayers

\footnotetext{
${ }^{2}$ Interview with Ade Putra, the member of Section Head of Acquisition Duty of Right on Land and Building Revenue Division of Pariaman
} 
to fill the form of Acquisition Duty of Right on Land and Building. The tax form that is not that easy to be understood will make the taxpayers difficult in tax payment because the new system of tax applies self-assessment system in which it requires the taxpayers to be active in filling the form. Therefore, the Public Notary/Land Deed Official is expected to minimize the level of difficulty of the taxpayers by helping them. Thus, the responsibility of taxpayers remains there in fulfilling their obligation everytime they pay the tax.

Acquisition Duty of Right on Land and Building because of conveyance of rights caused by trade must be paid prior to the deed of rights on land and or building is signed by the Public Notary/Land Deed Official. Land Affairs Agency has an authority in terms of granting new rights and in terms of conveyance of rights because of judge decision and will grant.

Taxpayers obtain rights on the land becaue of the conveyance of rights and the grant of new rights. The conveyance of rights that frequently happens in the community is caused by the trade with land and or building object. In trade, the thing that must be noticed is that the taxable object is not in dispute. The trade of land and or building is based on transaction value, ${ }^{3}$ which is the value that occurs and has been agreed by the related parties. Besides referring to the transaction value, especially out of trade, it is also based on market value which is the average value of trade transaction normally that occurs around the land position and or the building position. The presence of Acquisition Value of Taxable Object imposition base on trade with other legal act is based on the Regional Regulation of Acquisition Value of Taxable Object of Pariaman which is caused by following higher regulation namely Law Number 20 of 2009 regarding Acquisition Duty of Right on Land and Building in Article 6 Sub-section (2) specifically the imposition base of Acquisition Value of Taxable Object on trade is transaction. Besides trade, the imposition base of Acquisition Value of Taxable Object is market value.

Person or an agency trades before the Public Notary/Land Deed Official. After agreement is made from the parties and through calculation based on transaction value, it is found that Acquisition Value of Taxable Object is higher or not equal to Acquisition Value of Non-Taxable Object or its result is not nil after being substracted with Acquisition Value of Non-Taxable Object which is of IDR 60.000.000;00 (sixty millions rupiah), then the person or the agency is imposed to Acquisition Duty of Right on Land and Building as shown in the form.

However, it must be noticed this Acquisition Duty of Right on Land and Building tax collection adopts fairness principle. One of the forms of fairness according to Adam Smith called "the four of Adam Smith" is Equality which is similarity/equality which means that similar or equal condition or the person who is in the same condition must be imposed by tax. ${ }^{4}$ In fairness principle, one of its priorities is the equal treatment to all taxpayers. In this Acquisition Duty of Right on Land and Building tax collection, there is a limit which is the taxpayers who have Sales Value of Taxable Object under IDR 60.000.000,(sixty millions rupiah) are not imposed by tax, so that the fairness is reflected in this Acquisition Duty of Right on Land and Building tax imposition. The taxpayers of Acquisition Duty of Right on Land and Building must pay the payable tax before the deed of trade is issued or signed by the Public Notary/Land Deed Offical. ${ }^{5}$ Deed here is used as the proof that trade on land and or building has been executed. In Pariaman, the price in Regional Tax Payment Slip of Acquisition Duty of Right on Land and Building must be similar to the price in the deed of trade. If it is not same, the National Land Agency will not process the conveyance of right sand the documents will be returned to the Land Deed Official.

Here, the thing that must be paid attention is when the agreement is made between the parties in the trade because it has possibilities that fraut in the calculation of Acquisition Value of Taxable Object will

\footnotetext{
${ }^{3}$ Article 4 sub-section (2) in Regional Regulation of Pariaman Number 2 of 2011

${ }^{4}$ Y. Sri Pudyatmoko, Introduction to Tax of Law, Revised Edition, Yogyakarta: Andi Publisher, 2007, p.43

${ }^{5}$ Article 9 sub-section (1) in Regional Regulation of Pariaman Number 2 of 2011
} 
be there. Based on the research done by the writer regarding to the fraut, in fact, incompatibily frequently occurs in the transaction value determination of Acquisition Duty of Right on Land and Building. In its practice, Regional Tax Payment Slip of Acquisition Duty of Right on Land and Building that should be based on the Regional Regulation of Pariaman which is filled with transaction value; it is even not agreed by the tax officials. They demand that it should be adjusted to the present market value. It should be known that not all transactions must be always in accordance with the market value. Most of taxpayers who sell their land sometimes apply price under the market value and the fact is the taxpayers must pay the tax above their transaction value. In addition, it is extremely harmful for the taxpayers because they must pay higher tax.

The realization of value determination of Acquisition Duty of Right on Land and Building is called verification. Verification done by Office for Management of Finance and Regional Revenue has been done since 2009 based on Law Number 28 of 2009 regarding Regional Tax and Regional Retribution. Previously, there is no verification term for Local Government because Acquisition Duty of Right on Land and Building is central tax. The region only obtains sharing profit from this Acquisition Duty of Right on Land and Building collection. This verification is caused by the distrust from the government to the Land Deed Official. The Land Deed Official previously has an authority to make his own Acquisition Duty of Right on Land and Building value that makes most of taxpayers decrease their transaction value so that the tax paid can be minimum. Therefore, the region needs to verify Acquisition Duty of Right on Land and Building so that tax can be paid as much as the real transaction value.

In 2018, there were 674 taxpayers of Acquisition Duty of Right on Land and Building with revenue total of Acquisition Duty of Right on Land and Building is of IDR 2.216.972.724. ${ }^{6}$ In January 2019, there was a problem occurring in Pariaman regarding this Acquisition Duty of Right on Land and Building. It was Mr. Bujang, the community of Pariaman, wanted to buy ricefield owned by Mr. Hendra with width of 2500 meters square; the trade transaction for each meter is IDR 80.000,- Mr. Hendra sold the land with the agreement that all costs and taxes were imposed to the buyer. Then, Mr. Bujang visited the Office of Public Notary/Land Deed Official namely Yurina Persada, SH.,M.Kn. to proceed the trade. The Public Notary/Land Deed Official asked the transaction value and wrote the value in the form of Acquisition Duty of Right on Land and Building. After that, the verification form of Acquisition Duty of Right on Land and Building was submitted to Office for Management of Finance and Regional Revenue of Pariaman to be verified. After several days, the form was not accepted by Office for Management of Finance and Regional Revenue party and the Public Notary asked Mr. Bujang to explain to Office for Management of Finance and Regional Revenue party that the value shown in the form is the real transaction value. However, the tax officials did not want to accept it and asked the taxpayer to increase the value as in accordance with the market value in Jati Village, Pariaman. Consequently, because Mr. Bujang wanted his documents to be processed soon, then Mr. Bujang tried to adjust the value as the request of tax official which was of IDR 110.000,- for each meter.

The calculation of Office for Acquisition Duty of Right on Land and Building done by Mr. Bujang if adjusted to his transaction value was 1.626 meter x IDR 80.000= IDR 130.080.000-Acquisition Value of Non-taxable Object. IDR 200.000.000 - IDR60.000.000 = IDR 70.080.000,- Tariff of Acquisition Duty of Right on Land and Building is 5\% after substraction result with Acquisition Value of Nontaxable Object is 5\% x IDR 70.080.000,= IDR 3.504.000,- Mr. Edi should only pay IDR 3.504.000,- but in fact, Mr. Bujang must pay IDR 5.943.000 based on the value determination of the Development Finance Comptroller, the value for each meter becomes IDR 110.000,- based on this calculation: 1.626 meter x IDR 110.000= IDR 178.860.000- Acquisition Value of Non-taxable Object.. IDR 178.860.000IDR 60.000.000= IDR 118.860.000,- Tariff of Acquisition Duty of Right on Land and Building is 5\% after substraction result with Acquisition Value of Non-taxable Object is 5\% x IDR 118.860.000,= IDR

${ }^{6}$ Data collected from Office for Management of Finance and Regional Revenue of Pariaman 
5.943.000,. By seeing the condition, the writer assumes that Mr. Bujak suffers financial loss. He must pay the tax that is not in line with their trade transaction.

Based on the case above, the writer asks this to one of the tax officials. They argued that they also value something based on market value. It is because the level of trust of tax officials started to be decreasing to the taxpayers because the taxpayers frequently provided value in Acquisition Duty of Right on Land and Building is far under the transaction value. The land officials still do not find solution of this case. They will not process Acquisition Duty of Right on Land and Building if it is not in line with the value that they determine. Consequently, the documents will be returned to the taxpayers.

The writer attempted several time to make a survey in other locations regarding to this Acquisition Duty of Right on Land and Building problem. In Padang, for example, the government of Padang has issued Major Regulation regarding oath that contains statement regarding the real transaction. This is one of document requirements in Acquisition Duty of Right on Land and Building of Padang, while Pariaman still not applies this because there is no instruction yet from the Mayor to make oath as one of the requirements in Acquisition Duty of Right on Land and Building. In Bungo Regency, Jambi, the value determination of Acquisition Duty of Right on Land and Building is adjusted to Sales Value of Taxable Object in Land and Building Tax, so that the verification of Acquisition Duty of Right on Land and Building does not need to make a survey to the field anymore and makes the process of the next Acquisition Duty of Right on Land and Building faster. According to the writer, the Oath Statement Letter needs to be tried by the government of Pariaman to increase trust of tax officials towards taxpayers.

The implementation of conveyance of right is started from the taxpayers visit the office of Public Notary to submit a proposal of right conveyance administration complered with all supporting documents. Then, the Land Deed Official asks Head of Land Affairs Agency to conduct an investigation on taxable object. Afterwards, the Land Deed Official prepares Deed Draft of Right Conveyance. Along with the procedure, the Land Deed Official accepts from of Regional Tax Payment Slip of Acquisition Duty of Right on Land and Building from Office for Management of Finance and Regional Revenue. After document completion, the Land Deed Official calculates and completes the information of taxable object. After finishing verification and completing Acquisition Duty of Right on Land and Building payment, the Land Deed Official just can continue to sign the conveyance of right and submit the documents back to National Land Agency.

Based on the contracting freedom principle, the implementation of trade is done prior to completing the verification requirement of Acquisition Duty of Right on Land and Building because in the contracting freedom principle, the parties are free to determine the value, price, width, and others in the contract. The deed of trade is the form of trade contract. According to law, the filling of Regional Tax Payment Slip of Acquisition Duty of Right on Land and Building should be done after the contract of trade is made in which at that time the parties agree the value of trade that will be conducted. The fact in the field clearly violates the law specifically one of contracting principles namely the principle of contracting freedom and the valid requirement of the contract in Article 1320 in Indonesian Civil Code which is the agreement of the parties. What is meant by this agreement is the agreement regarding the price of trade of the parties.

Based on the procedure in the field, the writer assumes that it is less effective and it hampers the performance of Land Deed Official. The regulation is better to be changed that if there is a party that is willing to do conveyance of right, both buyer and seller, the first one to be consulted is Office for Management of Finance and Regional Revenue in order to adjust with the value that should be shown in Regional Tax Payment Slip of Office for Management of Finance and Regional Revenue. The next prosess can be done in the Land Deed Official in order that the performance of Land Deed Official is not hampered and can be more effective and efficient. 
Verification Determination of Acquisition Duty of Right on Land and Building towards Inheritance by Office for Management of Finance and Regional Revenue in Pariaman

The value determination of Acquisition Duty of Right on Land and Building in inheritance is approximately same as the value determination on trade. The difference is the inheritance absolutely applies market value because there is no transaction in inheritance. The requirements are also different. The mechanisms of Acquisition Duty of Right on Land and Building collection on Inheritance in Pariaman are as follows: ${ }^{7}$

1. The first phase done by the Heirs if they are granted the inheritance in form of land and building is administering the death certificate of the testator in the village or in the sub-district first;

2. Afterwards, Acquisition Duty of Right on Land and Building on the inheritance is administered (filling out the forms or the proposal requirements of Acquisition Duty of Right on Land and Building on inheritance) such as Statement Letter, Regional Tax Payment Slip of Acquisition Duty of Right on Land and Building, Notice of Tax Assessment of Urban Land and Building Tax, and attaching requirements that have been determined such as Death Certificate, Inheritance Certificate, Notice of Payable Tax of Land and Building Tax, and Land and Building Ceritificate. Administering Acquisition Duty of Right on Land and Building on Inheritance can be done individually by visiting Office for Management of Finance and Regional Revenue of Pariaman or can be done through Public Notary when the Heirs make Inheritance Certificate;

3. Filling out Regional Tax Payment Slip of Acquisition Duty of Right on Land and Building to be verified;

4. After being verified by Office for Management of Finance and Regional Revenue of Pariaman, then it is submitted to National Land Agency for doing Certificate Title Transfer; and

5. The last phase is Deed of Rights Allocation is made before and legalized by the Public Notary if the inheritance is in form of land and building is made on behalf of one of the heirs.

Market value is fair value. Before the appraiser determines the market value on Acquisition Duty of Right on Land and Building collection on inheritance, the parties of Office for Management of Finance and Regional Revenue condut a survey first or come to the field to collect data after the documents of Acquisition Duty of Right on Land and Building on inheritance are submitted by taxpayers to Office for Management of Finance and Regional Revenue of Pariaman. After collecting data, the tax officials on this survey come to the survey coordination, and then the survey coordinator assesses the data of Acquisition Duty of Right on Land and Building. After it is assessed, the appraiser should just come to the assessment.

The appraiser assesses and determines Sales Value of Taxable Object and Market Value on whether it is in line or in accordance with the existing data that have been submitted by taxpayers when doing Acquisition Duty of Right on Land and Building registration. In Office for Management of Finance and Regional Revenue, the appraiser consists not only 1 (one) person but it could be more. All these appraisers in determining Sales Value of Taxable Object are different. Their opinions are not always similar when they know the object condition. Afterwards, fair market value is discussed towards each Acquisition Duty of Right on Land and Building in order to obtain the value of Acquisition Duty of Right on Land and Building.

The verification realization of Acquisition Duty of Right on Land and Building in inheritance in Pariaman has been in line with Article 4 of Regional Regulation of Acquisition Duty of Right on Land

\footnotetext{
${ }^{7}$ Interview with Mr. Ade Putra, the member of Section Head in Service Division of Acquisition Duty of Right on Land and Building
} 
and Building in Pariaman in which the Imposition Base of Acquisition Value of Taxable Object is the market value. The market value is the appraisal value based on the prevailing market price in the transaction around the taxable object. Market is the meeting point between seller and buyer to have a transaction. Thus, if it is disuccsed, inheritance does not have a transaction in it. This inheritance is caused by estate from the testator who has kinship relation, marriage relation, or others. There is no transaction in this inheritance; thus, it should be no assessment value based on the market value in this inheritance. Acquisition Duty of Right on Land and Building on Inheritance should be based on the Sales Value of Taxable Object that prevails in each taxable object.

The realization of Acquisition Duty of Right on Land and Building on Inheritance with this field survey should not be done anymore because this verification method has been there. Hence, Office for Management of Finance and Regional Revenue should have verification data from every region in Pariaman. Therefore, field survey should not be done anymore in order to make the time more efficient and it can make its realization faster in the future.

Legal Consequence of Verification of Acquisition Duty of Right on Land and Building by Office for Management of Finance and Regional Revenue towards Contract of Trade Made by Land Deed Official in Pariaman.

Legal consequence is the consequence caused by legal events. Legal event is all events that can lead to legal consequence among the parties that have legal relation. The presence of verification of Acquisition Duty of Right on Land and Building by Office for Management of Finance and Regional Revenue towards the deed of Land Deed Official in Pariaman is based on Regional Regulation of Pariaman Number 2 of 2011 regarding Acquisition Duty of Right on Land and Building. The fact in the field shows that it is not in line with this Regional Regulation. Acquisition Duty of Right on Land and Building on Trade in the field is done not based on the market value, while in the Regional Regulation, it is done based on transaction value. Therefore, the verification of Acquisition Duty of Right on Land and Building harms the taxpayers. The absence of legal certainty on value determination of Acquisition Duty of Right on Land and Building leads to the condition in which it sometimes uses market value and sometimes uses transaction value. This brings to the absence of legal certainty. The length of value determination process in Acquisition Duty of Right on Land and Building will cause fatal condition namely if one of the parties in the trade contract is dead, the process will be continued by the heirs. This could lead to the dispute eventually.

The legal consequence of deed of Land Deed Official towards the verification of Acquisition Duty of Right on Land and Building by Office for Management of Finance and Regional Revenue of Pariaman is the deed is valid; therefore, as long as the deed of Land Deed Official fulfills the subjective and objective requirements of contract as shown in Article 1320 of Civil Code and it is made by the authorized official by referring to the law as mentioned in Article 1868 of Civil Code. The valid requirements of a contract according to Civil Code are as follows:

1. There is a consensus of willingness (Consensus, Agreement)

2. The authority or the capacity to act according to law (Capacity)

3. Particular object/matter

4. Allowed/valid/legal causa

The consequence of verification determination of Acquisition Duty of Right on Land and Building by Office for Management of Finance and Regional Revenue towards Land Deed Official is the long period of verification of Acquisition Duty of Right on Land and Building that makes the performance of Land Deed Official stops. As mentioned in Article 9 sub-section (1) in Regional Regulation of 
Acquisition Duty of Right on Land and Building of Pariaman, it is stated that "Land Deed Official/Public Notary can only sign the deed of conveyance of rights on land and/or building after the taxpayer submits the Regional Tax Payment Slip". It means that the conveyance of right only occurs if the verification of Acquisition Duty of Right on Land and Building is completed. If it is not completed yet, the process of conveyance of right cannot be continued yet.

The value in the form of Acquisition Duty of Right on Land and Building is determined by the party of Office for Management of Finance and Regional Revenue and there is no authority of the Public Notary/Land Deed Official in this Acquisition Duty of Right on Land and Building value determination. Acquisition Duty of Right on Land and Building uses self-assessment system which means that the obligation to pay tax is in the taxpayers themselves. Some parties give all processes to the Public Notary/Land Deed Official; thus, the filling of Acquisition Duty of Right on Land and Building form in Pariaman is mostly done by the Public Notary/Land Deed Official based on the transaction value explained by the seller and the buer to the Public Notary/Land Deed Official.

The realization of Acquisition Duty of Right on Land and Building on Trade in Pariaman does not fulfill the valid requirements of contract in which there should be an agreement of willingness between the parties. If the value of Acquisition Duty of Right on Land and Building is determined by Office for Management of Finance and Regional Revenue, these valid requirements are violated and this contract is null and void on willingness in which the willingness of the parties is not fulfilled. In addition, this contract is null and void based on law.

\section{Conclusion}

1. Determination verification of Acquisition Duty of Right on Land and Building by Office for Management of Finance and Regional Revenue of Pariaman based on Article 4 sub-section (2) in Regional Regulation of Pariaman Number 2 of 2011 regarding Acquisition Duty of Right on Land and Building states that Imposition Base of Acquisition Value of Taxable Object on Trade is transaction value. Transaction value is the value that has occurred and that has been agreed by the related parties. However, in the field, it is determined by market value in which it is the prevailing sales value in a particular area. The realization has violated the principle of contracting freedom and the valid requirement namely willingness agreement of the parties.

2. Verification of Acquisition Duty of Right on Land and Building on Inheritance done by Office for Management of Finance and Regional Revenue in Pariaman is done based on market value as in line with the Regional Regulation of Acquisition Duty of Right on Land and Building in which it should be determined based on Sales Value of Taxable Object only, not the market value because the market value has transaction. Inheritance does not have transaction in it; it is only estate from the family based on kinship relation, marriage relation, and so forth. Its value determination is same as Acquisition Duty of Right on Land and Building on Trade.

3. The presence of Acquisition Duty of Right on Land and Building verification by Office for Management of Finance and Regional Revenue towards the deed of Land Deed Official in Pariaman based on Regional Regulation of Pariaman Number 2 of 2011 regarding Acquisition Duty of Right on Land and Building is not in line with the fact in the field. If a contract of trade or deed of trade has fulfilled the requirements, then it is valid. In its realization, the contract of trade on this land trade is frequently null and void on wiliness because the absolute value is determined by Office for Management of Finance and Regional Revenue and it makes the contract null and void based on law because it does not fulfill the subjective requirements of trade. 


\section{References}

Books

Adjie, H. (2008). Sanksi perdata \& administratif terhadap notaris sebagai pejabat publik. Refika Aditama.

Asshiddiqie, J. (2003). Independensi Dan Akuntabilitas Pejabat Pembuat Akta Tanah. Jakarta: Renvoi.

Banakar, R., \& Travers, M. (Eds.). (2005). Theory and method in socio-legal research. Bloomsbury Publishing.

Darusman, Y. M. (2016). Kedudukan notaris sebagai pejabat pembuat akta otentik dan sebagai pejabat pembuat akta tanah. ADIL: Jurnal Hukum, 7(1), 36-56.

Juwana, H. (2006). Legal education reform in Indonesia. Asian Journal of Comparative Law, 1(1), 19320205 .

Lambert, V. A., \& Lambert, C. E. (2012). Qualitative descriptive research: An acceptable design. Pacific Rim International Journal of Nursing Research, 16(4), 255-256.

Lawless, R. M., Robbennolt, J. K., \& Ulen, T. (2010). Empirical methods in law (p. 172). New York: Aspen Publishers.

McConville, M. (Ed.). (2017). Research methods for law. Edinburgh University Press.

Pratama Putri, A. T. I. K. A. (2018). Efektivitas Pemungutan Pajak Restoran Dalam Meningkatkan Pendapatan Asli Daerah Kota Pariaman Provinsi Sumatera Barat (Doctoral dissertation, IPDN).

Legislation

The 1945 Constitution of the Republic of Indonesia

Law No. 23 of 2014 concerning Regional Government

Law No. 17 of 2003 concerning State Finance

Law No. 30 of 2014 concerning Government Administration

Law No. 20 of 2000 concerning Amendment to Law No. 21 of 1997 concerning Fees for the Acquisition of Rights to Land and Buildings (BPHTB)

Law No. 28 of 2009 concerning Regional Taxes and Regional Levies

Law No. 12 of 1994 concerning Amendment to Law No. 12 of 1985 concerning Land and Building Tax

Government Regulation No. 111 of 2000 concerning Imposition of Fees for the Acquisition of Rights to Land and Buildings (BPHTB) due to Inheritance and Probate Grant

Government Regulation No. 37 of 1998 concerning Regulations for Conveyancer Position

Government Regulation No. 58 of 2005 concerning Regional Financial Management 
Regional Regulation of Pariaman City No. 2 of 2011 concerning the Fees for the Acquisition of Rights to Land and Buildings

Regulation of Pariaman Mayor No. 44 of 2018 concerning the Position, Organizational Structure, Duties and Functions, and Work Procedures of the Financial Management Agency and the Regional Revenue of Pariaman City

Regulation of Pariaman Mayor No. 13 of 2011 concerning Systems and Procedures for Collecting Fees for the Acquisition of Rights to Land and Land Buildings in Pariaman City

\section{Copyrights}

Copyright for this article is retained by the author(s), with first publication rights granted to the journal.

This is an open-access article distributed under the terms and conditions of the Creative Commons Attribution license (http://creativecommons.org/licenses/by/4.0/). 